\title{
PERENCANAAN JADWAL DAN RUTE DISTRIBUSI ROKOK UNTUK MENEKAN TOTAL BIAYA TRANSPORTASI
}

\author{
THOMY EKO SAPUTRO DAN APRILIA PRIHATINA \\ Jurusan Teknik Industri, Fakultas Teknik, Universitas Muhammadiyah Malang \\ Laman: thoms.engineering@gmail.com
}

\begin{abstract}
ABSTRAK
Salah satu hal yang berpengaruh dalam meningkatkan pelayanan konsumen adalah bagaimana mengirimkan produk yang tepat waktu kepada seluruh konsumen. Oleh karena itu pelaku bisnis perlu menerapkan suatu strategi yang tepat agar dapat mengefisienkan dan mengefektifkan proses distribusinya. PR 567 sebagai distributor rokok perwakilan Purwodadi berupaya agar pendistribusian berjalan dengan baik karena mengingat proses distribusi dengan jumlah agen yang cukup banyak seringkali mempersulit distributor untuk menentukan jadwal dan rute yang tepat. Permasalahan pendistribusian ini termasuk dalam PVRP (Periodic Vehicle Routing Problem). Penyelesaian dilakukan menggunakan metode cluster first-second route dengan penugasan agen ke hari kunjungan menggunakan metode optimasi. Solusi akhir nantinya akan memberikan jadwal dan rute kendaraan dengan total biaya tranportasi yang paling minimum. Pada penelitian ini wilayah distribusi dibagi menjadi 2 cluster dan dari penyelesaian model PVRP diperoleh frekuensi kunjungan yang tepat untuk cluster 1 adalah sebanyak sekali dalam seminggu. Sedangkan untuk cluter 2 dikunjungi sebanyak 3 kali dalam seminggu. Hasil penentuan jadwal dan rute dari penelitian inimemberikan total biaya transportasi sebesar Rp725.805 per minggu. Dengan kata lain terjadi penghematan sebesar Rp320.189/minggu atau menghemat sebesar 44\% per minggu dari biaya awal yang harus dikeluarkan.
\end{abstract}

Kata kunci: Vehicle routing, periodic, nearest neighbour, optimasi

\begin{abstract}
One of the main issue in improving the customer service is how to deliver the product on time to customers. Therefore, the stakeholders need to apply an appropriate strategy in order to make distribustion process become more efficient and effective. Because it is hard to determine appropriate schedule and route when dealing with a lot agents, PR 567 as a representative distributor of cigarette in Purwodadi attempts to make its distribution process better. This was done by using PVRP (Periodic Vehicle Routing Problem) model with cluster first-second route approach and optimization method for assigning vehicle. The result of this research were frequency, schedule, and route with the most minimum transportation cost. In this research, the distribution area was defined into two cluster. The best delivery frequency for cluster one was once week, while cluster two was three times a week. The transportation cost was Rp725805/week. In the other hand, the saving cost was Rp320189/week or 44\%/week from the initial cost.
\end{abstract}

Key words: Vehicle routing, periodic, nearest neighbour, optimization

\section{PENDAHULUAN}

Kemampuan untuk mengirimkan produk ke pelanggan secara tepat waktu, dalam jumlah yang sesuai dan dalam kondisi yang baik sangat menentukan apakah produk tersebut pada akhirnya akan kompetitif di pasar. Penjadwalan dan penentuan rute pengiriman adalah pekerjaan yang sulit dan apabila tidak tepat akan berimplikasi keterlambatan pengiriman dan biaya transportasi Pujawan (2005). Salah satu hal yang berpengaruh dalam meningkatkan pelayanan konsumen adalah bagaimana menyediakan pengiriman produk yang tepat waktu kepada seluruh konsumen. Mengingat hal ini, maka pelaku bisnis perlu menerapkan suatu strategi yang tepat agar dapat mengefisienkan dan mengefektifkan proses distribusinya.

Menurut Prana (2007), dalam Periodic Vehicle Routing Problem atau PVRP, VRP (Vehicle Routing Problem) digeneralisasi dengan memperluas rentang perencanaan pengiriman menjadi $\mathrm{M}$ hari, dari semula hanya dalam rentang sehari. PVRP dapat dilihat sebagai masalah pengaturan sekelompok rute untuk tiap hari sehingga batasan-batasan yang ada terpenuhi dan biaya keseluruhan dapat diminimalisasi. Pemecahan Periodic Vehicle Routing Problem (PVRP) dapat diselesaikan dengan dua metode pendekatan, yakni metode optimal/eksak dan heuristik. Metode optimal/eksak ini menggunakan 
perhitungan model matematis linier programming, integer programming, dan mixed programming. Sedangkan dengan menggunakan metode heuristik, Beltramani dan Bodin mempertimbangkan dua pendekatan untuk penyelesaian masalah PVRP salah satunya yakni cluster first route second, dengan pendekatan ini yang pertama kali dilakukan adalah menugaskan tiap agen ke hari kunjungan dan selanjutnya menentukan rute kunjungan pada tiap harinya (Golden dkk., 2008).

Objek penelitian ini adalah PR. 567, salah satu distributor rokok yang berada di daerah Purwodadi. Wilayah pemasaran PR. 567 tidak hanya di Purwodadi tetapi mencakup beberapa wilayah seperti Wirosari, Kradenan, Gabus, Pulo kulon dan Tawang Harjo. Distributor sering kali mengalami kendala pada proses penjadwalan pengiriman, hal ini dikarenakan jumlah permintaan tiap agen berbeda-beda. Selama ini distributor kurang memperhatikan jadwal dan rute kunjungan yang tidak ada ketentuan dalam pendistribusian rokok, dari sisi rute pembagian rute untuk masing-masing kendaraan kurang memperhatikan jarak antar agen sehingga jarak yang ditempuh menjadi jauh dan total waktu satu perjalanan cukup lama yang berdampak pada tingginya biaya transportasi. Pada penelitian ini akan menggunakan metode heuristik cluster first-route second. Dimana pada tahap penugasan agen ke hari kunjungan menggunakan optimasi dengan model integer programming dan pada tahap penentuan rute kunjungan diselesaikan dengan metode heuristik nearest neighbour.

\section{METODE}

Metode pendekatan yang digunakan untuk menyelesaikan model PVRP ini adalah heuristik dengan teknik cluster first-route second. Seperti pada langkah-langkah dibawah ini, untuk cluster atau penugasan agen ke hari kunjungan dimulai pada langkah 1 sampai dengan langkah 3. Kemudian tahap penentuan rute pada tiap hari kunjungan dilakukan pada langkah 4 . Tahapan dalam penyelesaian permasalahan PVRP pada penelitian ini adalah sebagai berikut:

\section{Langkah 1. Penentuan frekuensi kunjungan}

Tahap pertama adalah penentuan frekuensi kunjungan, yang didasarkan pada panjang periode yang ditetapkan berdasarkan kondisi di distributor. Adapun panjang periode di dalam penelitian ini adalah selama 6 hari. Frekuensi kunjungan yang ditetapkan adalah 1, 2, 3, dan 6 .
Tabel 1. Frekuensi Kunjungan dan Kombinasi Hari Kunjungan untuk Periode 6 Harian

\begin{tabular}{ccccccc}
\hline $\mathbf{F}$ & \multicolumn{6}{c}{$\mathbf{S}$} \\
\cline { 2 - 7 } & $\mathbf{\# 1}$ & $\mathbf{\# 2}$ & $\mathbf{\# 3}$ & $\mathbf{\# 4}$ & $\mathbf{\# 5}$ & $\mathbf{\# 6}$ \\
\hline $\mathbf{1}$ & 100000 & 010000 & 001000 & 000100 & 000010 & 000001 \\
$\mathbf{2}$ & 100100 & 010010 & 001001 & & & \\
$\mathbf{3}$ & 101010 & 010101 & & & & \\
$\mathbf{6}$ & 111111 & & & & & \\
\hline
\end{tabular}

Tabel 1 menunjukkan frekuensi kunjungan dan kombinasi kunjungan untuk $m=6$. Urutan 6 digit yang digunakan pada tabel mewakili hari kunjungan, dimana 1 mengindikasikan bahwa terjadi kunjungan di sejumlah hari tersebut dan 0 mengindikasikan sebaliknya.

Langkah 2. Penentuan jumlah pengiriman sesuai dengan frekuensi kunjungan

Tahap kedua adalah penentuan jumlah pengiriman. Penentuan jumlah pengiriman untuk masingmasing agen ditentukan dengan menggunakan model persediaan klasik economic lot size yang diformulasikan Rusdiansyah dan Tsao (2005) sebagai berikut:

$q_{i}=q_{i r}=\lambda \frac{m}{f_{i}}=\frac{D_{i}}{f_{i}} \quad i \in I: r=1, \ldots, f_{i}$

Dimana:

$\lambda_{i}=$ laju permintaan setiap retailer $\mathrm{i} \in \mathrm{I}$ (unit produk per hari)

$m=$ panjang periode (hari)

$D_{i}=$ total permintaan setiap retailer

$f_{i}=$ interval ukuran pengiriman selama periode $m$ hari

$q_{i}=$ besarnya ukuran pengiriman setiap retailer $i$ $\in I$ (unit produk)

Masing-masing retailer $i \in I$ memiliki laju permintaan $\lambda i$ unit produk per hari. Jadi, selama $m$ day period, masing-masing retailer $i \in I$ memiliki permintaan total $D_{i}$. Selama periode, retailer $i \in$ $I$ memerlukan pengisian kembali (replenisment) sebanyak $f_{i}$ kali dengan jumlah pengiriman $q_{1}, q_{2}, \ldots$ $q_{i r}, \ldots, q_{i f i}$.

Langkah 3. Penugasan agen ke hari kunjungan

Tahap berikutnya adalah penugasan agen ke hari kunjungan. Dalam tahap ini setiap agen akan ditugaskan ke dalam satu hari atau lebih untuk dilakukan kunjungan berdasarkan frekuensi kunjungan yang telah ditentukan. Penyelesaian model PVRP di dalam menentukan penugasan agen 
ke hari kunjungan menggunakan metode optimasi yang diadopsi dari model matematis IPVRPTW yang dikembangkan oleh Rusdiansyah dan Tsao (2005). Namun, model matematis IPVRPTW Rusdiansyah dan Tsao (2005) tidak secara murni akan diadopsi akan tetapi akan dimodifikasi terlebih dahulu untuk disesuaikan dengan real objek permasalahan yang dihadapi yakni sesuai model PVRP.

Dari model matematis tersebut dimodifikasi dengan menjadikan frekuensi kunjungan sebagai parameter yang tetap (bukan variabel keputusan), menghilangkan komponen biaya simpan pada fungsi tujuan dan meniadakan batasan tour duration dan time windows. Sehingga dari hasil modifikasi model IPVRPTW tersebut menghasilkan formulasi seperti dibawah ini.

Minimize TC $\sum_{i \in I} \sum_{t \in T} \sum_{k \in K} C_{i} q_{i} X_{i t k}$

Subject to:

$\sum_{t \in T} y_{i t}=f_{i}, i \in I$

$\sum_{r+t+1}^{r=\frac{m}{f_{i}}+t} y_{i r}=1, t=0, \ldots \ldots,\left(m-\frac{m}{f_{i}}\right), i \in I$

$\sum_{i \in I} q_{i} X_{i t k} \leq C_{k}, t \in T, k \in K$

$\sum_{k \in K} X_{i t k}-y_{i t k}=0, t \in T, i \in I$

$y_{i t}, X_{i t k} \in 0,1$

Parameter:

$\mathrm{r}$ = Kombinasi hari kunjungan

$\mathrm{m}$ = panjang periode waktu

$\mathrm{f}_{\mathrm{i}}=$ frekuensi kunjungan pada agen ke- $i$

$\mathrm{q}_{\mathrm{i}}=$ jumlah produk yang dikirim ke agen ke- $i$

$\mathrm{C}_{\mathrm{k}}=$ kapasitas kendaraan ke- $k$

$\mathrm{C}_{\mathrm{i}}=$ biaya transportasi per unit dari distributor ke agen ke- $i$

Variabel keputusan:

$\mathrm{Y}_{\mathrm{it}}=$ bernilai 1 jika agen ke- $i$ akan dikunjungi pada hari kunjungan ke-t

$\mathrm{X}_{\mathrm{itk}}=$ bernilai 1 jika kendaraan ke- $k$ mengunjungi agen ke- $i$ pada hari kunjungan ke- $t$

Langkah 4. Penentuan rute kunjungan pada setiap harinya

Setelah semua agen masuk ke hari kunjungan, untuk menentukan rute kunjungan tahap ini digunakan metode nearest neighbour. Rute perjalanan dibuat dengan menambahkan konsumen terdekat dari titik terakhir yang dikunjungi oleh kendaraan. Iterasi dimulai dari DC kemudian perjalanan dilakukan menuju ke agen yang paling dekat dengan DC, dan seterusnya. Dengan kata lain mulai dari DC, prosedur ini menambah agen yang terdekat untuk melengkapi trip. Pada tiap langkah, trip dibangun dengan menambahkan agen yang terdekat dari titik terakhir yang dikunjungi oleh kendaraan sampai semua agen terkunjungi.

\section{HASIL DAN PEMBAHASAN}

\section{Clustering Agen}

Menurut Ballou (2004), rute kendaraan harus cluster yang saling berdekatan satu sama lain untuk meminimasi total jarak yang ditempuh oleh setiap kendaraan. Pada tahapan clustering customer dimana hal ini merupakan pengelompokan customer (agen) ke dalam beberapa cluster. Dari data alamat atau lokasi terlihat kedekatan agen sehingga diputuskan dalam penelitian ini untuk melakukan pengklusteran agen berdasarkan jumlah kendaraan dan kedekatan agen.

Jumlah cluster ditentukan oleh peneliti dimana sebanyak 2 cluster. Hal ini didasari oleh kedekatan antar agen dan distributor. Untuk proses clustering dilihat kedekatan agen antar kecamatan dan daerah, sehingga yang terpilih adalah agen-agen yang berdekatan jaraknya. Dengan mempertimbangkan jarak antar agen dalam kondisi nyata, maka dilakukan penukaran secara subjektif oleh peneliti dengan mempertimbangkan daerah/kecamatan yang paling dekat serta wilayah pembagian awal distributor. Selain itu distributor memiliki 2 kendaraan yang melakukan proses pendistribusian rokok. Setiap harinya terdapat 2 kendaraan yang ditugaskan untuk mengirim produk kepada agen, juga mendasari penentuan cluster sebanyak 2 cluster.

\section{Penentuan Jumlah Pengiriman ke Agen}

Pada tahapan ini dilakukan penentuan $q_{i}$ (jumlah pengiriman) yaitu besarnya kuantitas produk yang dikirimkan untuk masing-masing agen PR. 567. Masing-masing agen PR. 567 memiliki permintaan yang berbeda. Selama periode, agen memerlukan pengisian kembali (replenisment) sebanyak $f_{i}$ kali dengan jumlah produk yang dikirim sebesar $q_{i 1}, q_{i 2}$.. $q_{i r}, \ldots, q_{i f}$.

Frekuensi kunjungan kendaraan (fi) diperoleh dari FPB dari panjang periode yang dikehendaki. Pada penelitian ini panjang periode yang digunakan adalah 6 , jadi kombinasi frekuensi kunjungannya adalah 1 , 2,3 , dan 6 . Semakin sering agen dikunjungi maka 
jumlah pengiriman akan semakin kecil sebaliknya apabila semakin sedikit agen dikunjungi maka jumlah pengiriman agen akan semakin besar. Hasil perhitungan jumlah pengiriman ke tiap agen pada cluster 1 dan 2 ditunjukkan pada Tabel 2 dan 3.

Tabel 2. Jumlah Pengiriman ke Agen pada Cluster 1

\begin{tabular}{|c|c|c|c|c|c|c|}
\hline \multirow[t]{2}{*}{ No } & \multirow[t]{2}{*}{ Kode } & \multirow{2}{*}{$\begin{array}{c}\text { Rata-rata } \\
\text { permintaan } \\
\text { per minggu }\end{array}$} & \multicolumn{4}{|c|}{$\begin{array}{c}\text { Jumlah } \\
\text { pengiriman }\left(q_{i}\right)\end{array}$} \\
\hline & & & $\mathbf{f}=\mathbf{1}$ & $f=2$ & $f=3$ & $f=6$ \\
\hline 1. Damai & A31 & 29 & 29 & 15 & 10 & 5 \\
\hline 2. Mbak Asih & A32 & 32 & 32 & 16 & 11 & 6 \\
\hline 3. Mbak Marni & A33 & 30 & 30 & 15 & 10 & 5 \\
\hline 4. Yoga Cell & A34 & 34 & 34 & 17 & 12 & 6 \\
\hline 5. Mungguh & A35 & 29 & 29 & 15 & 10 & 5 \\
\hline 6. Sita & A36 & 31 & 31 & 16 & 16 & 6 \\
\hline 7. Jaya Sentosa & A13 & 30 & 30 & 15 & 10 & 5 \\
\hline 8. Fadli & A14 & 36 & 36 & 18 & 12 & 6 \\
\hline 9. Utama & A20 & 38 & 38 & 19 & 13 & 7 \\
\hline 10. Toko Budi & A28 & 37 & 37 & 19 & 13 & 7 \\
\hline $\begin{array}{l}\text { 11. Teguh } \\
\text { Santoso }\end{array}$ & $\mathrm{A} 1$ & 29 & 29 & 15 & 10 & 5 \\
\hline 12. Putra Jaya & $\mathrm{A} 2$ & 33 & 33 & 17 & 11 & 6 \\
\hline 13. 19 & A3 & 37 & 37 & 19 & 13 & 7 \\
\hline 14. The Mohing & A4 & 33 & 33 & 17 & 11 & 6 \\
\hline 15. 22 & A5 & 32 & 32 & 16 & 11 & 6 \\
\hline 16. Serba Ada & A6 & 30 & 30 & 15 & 10 & 5 \\
\hline 17. Makmur & A17 & 38 & 38 & 19 & 13 & 7 \\
\hline 18. Tri Tunggal & A19 & 29 & 29 & 15 & 10 & 5 \\
\hline
\end{tabular}

Tabel 3. Jumlah Pengiriman ke Agen pada Cluster 2

\begin{tabular}{|c|c|c|c|c|c|c|}
\hline \multirow[t]{2}{*}{ Agen } & \multirow[t]{2}{*}{ Kode } & \multirow{2}{*}{$\begin{array}{c}\text { Rata-rata } \\
\text { permintaan } \\
\text { per minggu }\end{array}$} & \multicolumn{4}{|c|}{$\begin{array}{c}\text { Jumlah } \\
\text { pengiriman }\left(q_{i}\right)\end{array}$} \\
\hline & & & $f=1$ & $f=2$ & $f=3$ & $f=6$ \\
\hline 1. $\mathrm{Al} \mathrm{Hikmah}$ & A24 & 34 & 34 & 17 & 12 & 6 \\
\hline 2. Toko Niaga & A25 & 33 & 33 & 17 & 11 & 6 \\
\hline 3. Murni & A26 & 39 & 39 & 20 & 13 & 7 \\
\hline 4. Toko Surya & A27 & 33 & 33 & 17 & 11 & 6 \\
\hline 5. S.S Agung & A29 & 36 & 36 & 18 & 12 & 6 \\
\hline 6. $\mathrm{Al} \mathrm{Amin}$ & A30 & 38 & 38 & 19 & 13 & 7 \\
\hline 7. Waris & A18 & 36 & 36 & 18 & 12 & 6 \\
\hline 8. Agung & $\mathrm{A} 21$ & 34 & 34 & 17 & 12 & 6 \\
\hline $\begin{array}{l}\text { 9. Jaya } \\
\text { Makmur }\end{array}$ & $\mathrm{A} 22$ & 36 & 36 & 18 & 12 & 6 \\
\hline $\begin{array}{l}\text { 10. Langgeng } \\
\text { Jaya }\end{array}$ & $\mathrm{A} 23$ & 30 & 30 & 15 & 10 & 5 \\
\hline 11. Unggul jaya & A7 & 37 & 37 & 19 & 13 & 7 \\
\hline 12. Utomo & A8 & 38 & 38 & 19 & 13 & 7 \\
\hline 13. Yanto & A9 & 36 & 36 & 18 & 12 & 6 \\
\hline 14. Rejeki & $\mathrm{A} 10$ & 35 & 35 & 18 & 12 & 6 \\
\hline 15. Sahabat & A11 & 36 & 36 & 18 & 12 & 6 \\
\hline 16. Lima - Lima & A12 & 35 & 35 & 18 & 12 & 6 \\
\hline $\begin{array}{l}\text { 17. Sarana } \\
\text { Mulya }\end{array}$ & $\mathrm{A} 15$ & 34 & 34 & 17 & 12 & 6 \\
\hline $\begin{array}{l}18 \text { Sumber } \\
\text { Rejeki }\end{array}$ & A16 & 36 & 36 & 18 & 12 & 6 \\
\hline
\end{tabular}

Jumlah pengiriman agen Damai pada frekuensi satu kali kunjungan dalam 1 periode sebesar 29, untuk frekuensi 2 yang mana berarti agen akan dikunjungi 2 kali dalam satu periode maka jumlah pengiriman $1 / 2$ dari jumlah rata-rata permintaan $f_{i}=1$ yakni 15, sedangkan untuk frekuensi 3 dimana agen akan dikunjungi sebanyak 3 kali dalam satu periode memiliki jumlah pengiriman $1 / 3$ dari jumlah ratarata permintaan $f_{i}=1$ yakni 10 sedangkan untuk frekuensi 6 dimana agen akan dikunjungi sebanyak 6 kali dalam satu periode memiliki jumlah pengiriman $1 / 6$ dari jumlah rata-rata permintaan $f_{i}=1$ yakni 5 , dan jumlah pengiriman produk selalu bilangan bulat, antara hari satu dengan hari berikutnya jumlahnya sama per frekuensi.

\section{Hasil Penugasan Agen ke Hari Kunjungan}

Hasil penugasan agen ke hari kunjungan yang diperoleh dengan bantuan software Lingo pada cluster 1 seperti yang ditunjukkan pada Tabel 4. Hasil penugasan kunjungan kendaraan pada $f_{i}=1$ dengan kendaraan 1 adalah: hari pertama mengunjungi agen Teguh Santoso, dan agen Serba Ada; hari kedua mengunjungi agen Putra Jaya, agen Fadli, dan agen Makmur; hari ketiga mengunjungi agen Mbak Asih; hari keempat mengunjungi agen The Mohing, agen Tri Tunggal, dan agen Sita; hari kelima mengunjungi agen 22, agen Utama, agen Toko Budi, agen Mbak Marni, agen Yoga Cell dan agen Mungguh; dan hari keenam mengunjungi agen 19, agen Jaya Santoso dan agen Damai.

Hasil penugasan pada Cluster 2 seperti yang ditunjukkan pada Tabel 5. Hasil penugasan kunjungan kendaraan pada $f_{i}=1$ dengan kendaraan 2 adalah: hari pertama mengunjungi agen Sahabat, agen Agung, agen $\mathrm{Al}$ Hikmah dan agen Toko Surya. Hari kedua mengunjungi agen Jaya Makmur, agen Murni, dan agen S.S Agung. Hari ketiga mengunjungi agen Lima-lima, agen Toko Niaga dan agen Al Amin. Hari keempat mengunjungi agen Waris, hari kelima mengunjungi agen Unggul Jaya, agen Yanto, agen Rejeki, agen Sarana Mulya dan agen sumber Rejeki. Hari keenam mengunjungi agen Utama, dan agen Langgeng Jaya.

\section{Rute Kunjungan ke Agen}

Berdasarkan hasil pengolahan LINGO yakni penugasan agen ke hari kunjungan, kemudian ditentukan rute kunjungannya dengan metode nearest neighbour. Selain itu dapat diketahui total jarak tempuh dari masing-masing frekuensi kunjungan 1. Berdasarkan Tabel 6, diperoleh rute cluster 1 yang memiliki jarak tempuh yang paling minimum terdapat pada frekuensi 1 yaitu sebesar $321,5 \mathrm{~km}$. Rute yang terbentuk adalah:

Hari ke-1: D-A6-A1-D

Hari ke-2: D-A14-A17-A2-D

Hari ke-3: D-A32-D

Hari ke-4: D-A36-A4-A19-D 
Tabel 4. Kombinasi Hari Kunjungan Cluster 1

\begin{tabular}{ll}
\hline \multicolumn{1}{c}{$\mathbf{f i ~} \mathbf{1}$} & \multicolumn{1}{c}{$\mathbf{f} \mathbf{c} \mathbf{2}$} \\
\hline Hari I :A1, A6 & Hari I :A1, A6, A13, A17, A19, A33, A36 \\
Hari II :A2, A14, A17 & Hari II : A2, A5, A32 \\
Hari III : A32 & Hari III :A3, A4, A14, A20, A28, A31, A34, A35 \\
Hari IV : A4, A19,A36 & Hari IV : A1, A6, A13, A17, A19, A33, A36 \\
Hari V : A5, A20, A28, A33, A34, A35 & Hari V : A2, A5, A32 \\
Hari VI : A3, A13, A31 & Hari VI : A3, A4, A14, A20, A28, A31, A34, A35 \\
\hline fi = 3 & $\mathbf{f i}=\mathbf{6}$ \\
\hline Hari I : A1, A2, A3, A4, A5, A6, A13, A14, A17, A19, A20, A28, & Hari I : A1, A2, A3, A4, A5, A6, A13, A14, A17, A19, A20, A28, A31, \\
A31, A32, A33, A34, A35, A36 & A32, A33, A34, A35, A36 \\
Hari II :- & Hari II : A1, A2, A3, A4, A5, A6, A13, A14, A17, A19, A20, A28, A31, \\
& A32, A33, A34, A35, A36 \\
Hari III : A1, A2, A3, A4, A5, A6, A13, A14, A17, A19, A20, & Hari III : A1, A2, A3, A4, A5, A6, A13, A14, A17, A19, A20, A28, \\
A28, A31, A32, A33, A34, A35, A36 & A31, A32, A33, A34, A35, A36 \\
Hari IV : - & Hari IV : A1, A2, A3, A4, A5, A6, A13, A14, A17, A19, A20, A28, A31, \\
& A32, A33, A34, A35, A36 \\
Hari V : A1, A2, A3, A4, A5, A6, A13, A14, A17, A19, A20, A28, Hari V : A1, A2, A3, A4, A5, A6, A13, A14, A17, A19, A20, A28, A31, \\
A31, A32, A33, A34, A35, A36 & A32, A33, A34, A35, A36 \\
Hari VI : - & Hari VI : A1, A2, A3, A4, A5, A6, A13, A14, A17, A19, A20, A28, A31, \\
& A32, A33, A34, A35, A36 \\
\hline
\end{tabular}

Tabel 5. Kombinasi Hari Kunjungan Cluster 2

\begin{tabular}{ll}
\hline \multicolumn{1}{c}{$\mathbf{f i}=\mathbf{1}$} & \multicolumn{1}{c}{$\mathbf{f i}=\mathbf{2}$} \\
\hline Hari I : A11, A21, A24,A27 & Hari I : A9, A10, A12, A16, A22, A23, A24, A26, A27, A29, A30 \\
Hari II : A22, A26, A29 & Hari II : A7, A18 \\
Hari III : A12, A25,A30 & Hari III : A8, A11, A15, A21, A25 \\
Hari IV : A18 & Hari IV: A9, A10, A12, A16, A22, A23, A24, A26, A27, A29, A30 \\
Hari V : A7, A9,A10,A15,A16 & Hari V : A7, A18 \\
Hari VI : A8, A23 & Hari VI: A8, A11, A15, A21, A25 \\
\hline fi $=\mathbf{3}$ & $\mathbf{f i}=\mathbf{6}$ \\
\hline Hari I : A7, A8, A9, A10, A11, A12, A15, A16, A18, A21, A22, & Hari I : A7, A8, A9, A10, A11, A12, A15, A16, A18, A21, A22, A23, \\
A23, A24, A25, A26, A27, A29, A30 & A24, A25, A26, A27, A29, A30 \\
Hari II :- & Hari II : A7, A8, A9, A10, A11, A12, A15, A16, A18, A21, A22, A23, \\
& A24, A25, A26, A27, A29, A30 \\
Hari III : A7, A8, A9, A10, A11, A12, A15, A16, A18, A21, A22, & Hari III : A7, A8, A9, A10, A11, A12, A15, A16, A18, A21, A22, A23, \\
A23, A24, A25, A26, A27, A29, A30 & A24, A25, A26, A27, A29, A30 \\
Hari IV : - & Hari IV : A7, A8, A9, A10, A11, A12, A15, A16, A18, A21, A22, A23, \\
& A24, A25, A26, A27, A29, A30 \\
Hari V : A7, A8, A9, A10, A11, A12, A15, A16, A18, A21, A22, & Hari V : A7, A8, A9, A10, A11, A12, A15, A16, A18, A21, A22, A23, \\
A23, A24, A25, A26, A27, A29, A30 & A24, A25, A26, A27, A29, A30 \\
Hari VI : - & Hari VI : A7, A8, A9, A10, A11, A12, A15, A16, A18, A21, A22, A23, \\
& A24, A25, A26, A27, A29, A30 \\
\hline
\end{tabular}

Hari ke-5: D-A34-A20-A28-A5-A33-A35-D

Hari ke-6: D-A31-A3-A13-D

Hasil rute cluster 2 diperoleh jarak tempuh yang paling minimum terdapat pada frekuensi 3 seperti ditunjukkan pada Tabel 7, dengan 1 kombinasi hari kunjungan yaitu pada hari ke-1, 3, dan 5. Total jarak tempuh sebesar 417,6 $\mathrm{km}$ dan rute yang terbetuk adalah:

Hari ke-1 : D-A30-A24-A25-A29-A26-A21-A22-A23A18-A15-A10-A12-A7-A8-A11-A9-A16A27-D.

Hari ke-3: D-A30-A24-A25-A29-A26-A21-A22-A23A18-A15-A10-A12-A7-A8-A11-A9-A16A27-D.
Hari ke-5: D-A30-A24-A25-A29-A26-A21-A22-A23A18-A15-A10-A12-A7-A8-A11-A9-A16A27-D.

Total jarak tempuh setelah menggunakan PVRP sebesar 739,1 km, sedangkan total jarak tempuh awal perusahaan sebesar $1322,7 \mathrm{~km}$.

\section{Penghematan Total Biaya}

Dari hasil perhitungan biaya transportasi yang paling minimum pada cluster 1 adalah pada frekuensi 1 yaitu sebesar Rp176.445, sedangkan biaya transportasi yang paling minimum pada cluster 2 adalah pada frekuensi 3 yaitu sebesar Rp229.171. Jadi total biaya transportasi dengan penerapan 
Tabel 6. Rute Kunjungan Agen pada Cluster 1

\begin{tabular}{|c|c|c|c|}
\hline Cluster $1 f_{i}=1$ & $\mathbf{K m}$ & Cluster $1 f_{i}=2$ & $\mathbf{K m}$ \\
\hline Hari I: D-A6-A1-D & 60,6 & Hari I :D-A33-A36-A13-A6-A1-A19-A17-D & 99,8 \\
\hline Hari II : D-A14-A17-A2-D & 84,9 & Hari II : D-A32-A5-A2-D & 86,6 \\
\hline Hari III : D-A32-D & 16,4 & Hari III : D-A31-A35-A14-A28-A20-A34-A3-A4-D & 86.6 \\
\hline Hari IV :D-A36-A4-A19-D & 66,5 & Hari IV : D-A33-A36-A13-A6-A1-A19-A17-D & 99,8 \\
\hline Hari V :D-A34-A20-A28-A5-A33-A35-D & 40,5 & Hari V : D-A32-A5-A2-D & 86.6 \\
\hline Hari VI : D-A31-A3-A13-D & 52,6 & Hari VI : D-A31-A35-A14-A28-A20-A34-A3-A4-D & 86.6 \\
\hline Total jarak & 321.5 & Total jarak & 546 \\
\hline Cluster $1 f_{i}=3$ & & Cluster $1 f_{i}=6$ & \\
\hline $\begin{array}{l}\text { Hari I: D-A34-A20-A28-A5-A4-A19-A17-A3-A13-A6-A1- } \\
\text { A2-A14-A33-A35-A32-A36-A31-D }\end{array}$ & 140,3 & $\begin{array}{l}\text { Hari I: D-A34-A20-A28-A5-A4-A19-A17-A3-A13-A6- } \\
\text { A1-A2-A14-A33-A35-A32-A36-A31-D }\end{array}$ & 140,3 \\
\hline Hari II : - & & $\begin{array}{l}\text { Hari II : D-A34-A20-A28-A5-A4-A19-A17-A3-A13-A6- } \\
\text { A1-A2-A14-A33-A35-A32-A36-A31-D }\end{array}$ & 140,3 \\
\hline $\begin{array}{l}\text { Hari III: D-A34-A20-A28-A5-A4-A19-A17-A3-A13-A6-A1- } \\
\text { A2-A14-A33-A35-A32-A36-A31-D }\end{array}$ & 140,3 & $\begin{array}{l}\text { Hari III: D-A34-A20-A28-A5-A4-A19-A17-A3-A13-A6- } \\
\text { A1-A2-A14-A33-A35-A32-A36-A31-D }\end{array}$ & 140,3 \\
\hline Hari IV : - & & $\begin{array}{l}\text { Hari IV : D-A34-A20-A28-A5-A4-A19-A17-A3-A13-A6- } \\
\text { A1-A2-A14-A33-A35-A32-A36-A31-D }\end{array}$ & 140,3 \\
\hline $\begin{array}{l}\text { Hari V: D-A34-A20-A28-A5-A4-A19-A17-A3-A13-A6-A1- } \\
\text { A2-A14-A33-A35-A32-A36-A31-D }\end{array}$ & 140,3 & $\begin{array}{l}\text { Hari V: D-A34-A20-A28-A5-A4-A19-A17-A3-A13-A6- } \\
\text { A1-A2-A14-A33-A35-A32-A36-A31-D }\end{array}$ & 140,3 \\
\hline Hari VI : - & & $\begin{array}{l}\text { Hari VI: D-A34-A20-A28-A5-A4-A19-A17-A3-A13-A6- } \\
\text { A1-A2-A14-A33-A35-A32-A36-A31-D }\end{array}$ & 140,3 \\
\hline Total & 420,9 & Total & 841,8 \\
\hline
\end{tabular}

Tabel 7. Rute Kunjungan Agen pada Cluster 2

\begin{tabular}{|c|c|c|c|}
\hline Cluster $2 f_{i}=1$ & $\mathbf{K m}$ & Cluster $2 f_{i}=2$ & $\mathbf{K m}$ \\
\hline Hari I: D-A27-A21-A24-A11-D & 137,9 & $\begin{array}{l}\text { Hari I: D-A30-A24-A26-A29-A22-A23-A10-A12-A16- } \\
\text { A9-A27-D }\end{array}$ & 135,5 \\
\hline Hari II : D-A26-A29-A22-D & 49,9 & Hari II : D-A18-A7-D & 81,2 \\
\hline Hari III :D-A30-A25-A12-D & 90,7 & Hari III :D-A21-A25-A15-A8-A11-D & 117.3 \\
\hline Hari IV :D-A18-D & 56,6 & $\begin{array}{l}\text { Hari IV : D-A30-A24-A26-A29-A22-A23-A10-A12-A16- } \\
\text { A9-A27-D }\end{array}$ & 135.5 \\
\hline Hari V :D-A15-A10-A16-A9-D & 120,2 & Hari V : D-A18-A7-D & 81.2 \\
\hline Hari VI : D-A23-A8-D & 78,1 & Hari VI : D-A21-A25-A15-A8-A11-D & 117.3 \\
\hline Total & 533.4 & Total & 668 \\
\hline Cluster $2 f_{i}=3$ & & Cluster $2 f_{i}=6$ & \\
\hline $\begin{array}{l}\text { Hari I : D-A30-A24-A25-A29-A26-A21-A22-A23-A18-A15- } \\
\text { A10-A12-A7-A8-A11-A9-A16-A27-D }\end{array}$ & 139,2 & $\begin{array}{l}\text { Hari I: D-A30-A24-A25-A29-A26-A21-A22-A23-A18- } \\
\text { A15-A10-A12-A7-A8-A11-A9-A16-A27-D }\end{array}$ & 139,2 \\
\hline Hari II : - & & $\begin{array}{l}\text { Hari II:D-A30-A24-A25-A29-A26-A21-A22-A23-A18- } \\
\text { A15-A10-A12-A7-A8-A11-A9-A16-A27-D }\end{array}$ & 139,2 \\
\hline $\begin{array}{l}\text { Hari III : D-A30-A24-A25-A29-A26-A21-A22-A23-A18- } \\
\text { A15-A10-A12-A7-A8-A11-A9-A16-A27-D }\end{array}$ & 139,2 & $\begin{array}{l}\text { Hari III:D-A30-A24-A25-A29-A26-A21-A22-A23-A18- } \\
\text { A15-A10-A12-A7-A8-A11-A9-A16-A27-D }\end{array}$ & 139,2 \\
\hline Hari IV :- & & $\begin{array}{l}\text { Hari IV :D-A30-A24-A25-A29-A26-A21-A22-A23-A18- } \\
\text { A15-A10-A12-A7-A8-A11-A9-A16-A27-D }\end{array}$ & 139,2 \\
\hline $\begin{array}{l}\text { Hari V :D-A30-A24-A25-A29-A26-A21-A22-A23-A18-A15- } \\
\text { A10-A12-A7-A8-A11-A9-A16-A27-D }\end{array}$ & 139,2 & $\begin{array}{l}\text { Hari V :D-A30-A24-A25-A29-A26-A21-A22-A23-A18- } \\
\text { A15-A10-A12-A7-A8-A11-A9-A16-A27-D }\end{array}$ & 139,2 \\
\hline Hari VI : - & & $\begin{array}{l}\text { Hari VI :D-A30-A24-A25-A29-A26-A21-A22-A23-A18- } \\
\text { A15-A10-A12-A7-A8-A11-A9-A16-A27-D }\end{array}$ & 139,2 \\
\hline Total & 417,6 & Total & 835,2 \\
\hline
\end{tabular}

PVRP per minggunya sebesar Rp405.616. Biaya transportasi per unit (ball) pada cluster 1 adalah pada frekuensi 1 yaitu sebesar Rp700,18, sedangkan biaya transportasi pada cluster 2 frekuensi 3 yaitu sebesar Rp909,4. Jadi total biaya transportasi per unit (ball) dengan penerapan PVRP per minggunya sebesar Rp1.609,58.

Perbandingan biaya sebelum dan sesudah penerapan model PVRP akan memberikan gambaran seberapa besar penurunan biaya yang terjadi. Biaya awal yang harus dikeluarkan oleh PR. 567 adalah sebesar Rp725.805 per minggu, dan biaya transportasi per unit (ball) sebesar Rp2.880,2 dimana perusahaan kurang memperhatikan jarak dan rute mana yang harus ditempuh serta aspek permintaan konsumen. Sedangkan setelah menerapkan model PVRP, biaya yang harus dikeluarkan oleh perusahaan adalah sebesar Rp405.616, dan biaya 
transportasi per unit (ball) sebesar Rp1.609,58. Terjadi penurunan biaya sebesar Rp320.189/minggu atau menghemat sebesar $44 \%$ per minggu dari biaya awal yang harus dikeluarkan PR. 567 yang mana apabila dikalkulasikan dalam 1 bulan maka besarnya penghematan yang akan diperoleh adalah sebesar Rp1.280.756/bulan, dan dalam satu tahun dapat menghemat sampai dengan Rp15.369.072/ tahun, sedangkan penurunan biaya transportasi per unit (ball) sebesar Rp1.270,62/minggu atau menghemat sebesar $44 \%$ per minggu dari biaya awal yang harus dikeluarkan PR. 567 yang mana apabila dikalkulasikan dalam 1 bulan maka besarnya penghematan yang akan diperoleh adalah sebesar Rp5082,48/bulan, dan dalam satu tahun dapat menghemat sampai dengan Rp60.989.76/tahun.

\section{SIMPULAN}

Dari hasil penyelesaian model PVRP dengan metode heuristik cluster first-second route dimana penugasan agen ke hari kunjungan diselesaikan dengan menggunakan metode optimasi yang dimodifikasi dari IPVRPTW yang dikembangkan oleh Rusdiansyah and Tsao (2005) telah memberikan solusi yang lebih baik dari sistim distribusi awal distributor saat ini. Hasil penyelesaian berupa jadwal dan rute kendaraan dapat memberikan penghematan total biaya transportasi yang cukup signifikan. Biaya awal yang harus dikeluarkan oleh PR. 567 adalah sebesar Rp725.805 per minggu. Sedangkan setelah menerapkan model PVRP, biaya yang harus dikeluarkan oleh distributor adalah sebesar Rp405.616 per minggu. Sehingga terjadi penurunan biaya sebesar Rp320.189/minggu atau menghemat sebesar $44 \%$ per minggu dari biaya awal yang harus dikeluarkan.

\section{DAFTAR PUSTAKA}

Ballou, R.H., 2004. Business Logistics Management: Planning, Organizing and Controlling the Supply Chain. Prentice Hall. News Jersey.

Golden, B., S. Raghavan, E. Wasil, 2008. The Vehicle Routing Problem: Latest Advances and New Challenges. Springer. New York.

Prana, A R., 2007. Aplikasi Kombinatoring pada Vehicle Routing Problem. Jurnal Teknik Informatika. ITB.

Pujawan, I.N., 2005. Supply Chain Management. Guna Widya. Surabaya.

Rusdiansyah, A. dan Tsao, D., 2005. An Integrated Model of The Periodic Delivery Problems for Vending Machine Supply Chains. Journal of Food Engineering 70, 421-434. 